Southern Illinois University Carbondale

OpenSIUC

$10-2007$

\title{
Influence of Stress and Dietary Natural-Source Vitamin E on Nonspecific Immunocompetence, Tissue Tocopherol Composition, and Postslaughter Fillet Oxidative Stability in Sunshine Bass
}

Jesse Trushenski

Southern Illinois University Carbondale

Christopher Kohler

Follow this and additional works at: http://opensiuc.lib.siu.edu/fiaq pubs

Published in North American Journal of Aquaculture, Vol. 69, Issue 4 (October 2007) at

DOI: 10.1577/A06-083.1

Copyright by the American Fisheries Society 2007

\section{Recommended Citation}

Trushenski, Jesse and Kohler, Christopher. "Influence of Stress and Dietary Natural-Source Vitamin E on Nonspecific

Immunocompetence, Tissue Tocopherol Composition, and Postslaughter Fillet Oxidative Stability in Sunshine Bass." (Oct 2007).

This Article is brought to you for free and open access by the Fisheries and Illinois Aquaculture Center at OpenSIUC. It has been accepted for inclusion in Publications by an authorized administrator of OpenSIUC. For more information, please contact opensiuc@lib.siu.edu. 


\title{
Influence of Stress and Dietary Natural-Source Vitamin $\mathbf{E}$ on Nonspecific Immunocompetence, Tissue Tocopherol Composition, and Postslaughter Fillet Oxidative Stability in Sunshine Bass
}

\author{
Jesse T. Trushenski* and Christopher C. Kohler \\ Fisheries and Illinois Aquaculture Center and Department of Zoology, \\ Southern Illinois University, Carbondale, Illinois 62901-6511, USA
}

\begin{abstract}
We evaluated the effects of stressor exposure and super-requirement levels of $R R R-\alpha$ tocopheryl acetate (natural-source vitamin E [NSVE]) on production performance and nonspecific immunocompetency of juvenile sunshine bass (female white bass Morone chrysops $\times$ male striped bass $M$. saxatilis). Stressor exposure elicited physiological changes consistent with the generalized stress response, and the magnitude of responses generally mirrored stressor severity. Stressor exposure resulted in lower fillet peroxides and greater aldehydes after short-term frozen storage, whereas increasing dietary NSVE was associated with a nonsignificant reduction in aldehydes after long-term storage. Fillet $\alpha$-tocopherol content increased linearly with dietary NSVE, exceeding reported tissue levels achieved with synthetic vitamin E (SYNE). Although we observed no significant immunological effects of stress or dietary NSVE content, sampling time and high individual-to-individual variation probably restricted our ability to resolve statistical significance. Similar results of vitamin E supplementation have previously been reported; however, the effective dietary concentrations we observed for NSVE are low in comparison with values reported for SYNE. The potential of $R R R$ - $\alpha$-tocopheryl acetate as a highly active vitamin E source for aquaculture feeds warrants further evaluation of the relative suitability of NSVE in meeting the demands of optimal aquaculture nutrition.
\end{abstract}

Many necessary culture practices are stressors to aquatic livestock; thus, physiological stress is a regular, if not constant, condition in aquaculture (Barton and Iwama 1991). Chronic stress results in immunosuppression (Tort et al. 2004) culminating in increased vulnerability to pathogens. Increased susceptibility to infection and high animal density make aquaculture production facilities ideal environments for disease outbreak. Furthermore, stressor exposure before slaughter can negatively affect product quality in terms of texture and organoleptic profile (Poli et al. 2005). Stress-related losses are limiting factors in fish culture, and it is clear that if culture activities are to flourish, these problems must be overcome.

Meeting nutritional requirements is essential for health, but some components of the diet may exert influence beyond their purely nutritional value (Gatlin 2002). Immunostimulative properties of certain dietary constituents may improve the overall robustness of innate disease resistance mechanisms (Erickson et al. 2000), and research to this effect is a growing field in animal science, including aquaculture nutrition (Irianto and Austin 2002). Vitamin E has long been associated with proper immune function in vertebrates, including fishes (Blazer and Wolke 1984; Hilton 1989; Fletcher

\footnotetext{
* Corresponding author: saluski@siu.edu
}

Received November 14, 2006; accepted March 26, 2007 Published online September 10, 2007
1997). As a potent lipid-soluble antioxidant (Bowry and Stocker 1993), vitamin E has received considerable attention in aquaculture nutrition as a candidate "nutriceutical" (Raa 2000) and as a means of enhancing postslaughter organoleptic stability of seafood products (Tocher et al. 2002, 2003; Huang and Huang 2004).

Although most of the tocopherols and tocotrienols have similar in vitro antioxidant activity (Zingg and Azzi 2004), $\boldsymbol{\alpha}$-tocopherol is acknowledged as being the most biologically active $\mathrm{E}$ vitamer (Hosomi et al. 1997). Of the eight possible stereoisomers of $\alpha$ tocopherol, $R R R$ - $\alpha$-tocopherol has the greatest potency in vivo (Burton et al. 1998; Brigelius-Flohé and Traber 1999). Despite the greater efficacy of $R R R$ - $\alpha$-tocopherol, animal feed manufacturers typically use synthetic vitamin E (SYNE; all-rac- $\boldsymbol{\alpha}$-tocopheryl acetate) to meet the vitamin $E$ requirements of livestock. Natural-source vitamin E (NSVE) is a purified source of $R R R-\alpha$ tocopherol (as $R R R$ - $\alpha$-tocopheryl acetate) and has been established as a more effective micronutrient source for sunshine bass (female white bass Morone chrysops $\times$ male striped bass $M$. saxatilis; Trushenski and Kohler 2006). Natural-source vitamin E may also be superior to SYNE in enhancing the immunocompetence and performance of aquatic livestock; however, these effects of NSVE in vivo and postslaughter have not previously been addressed. Accordingly, we evaluated the effects of super-requirement dietary levels of NSVE on production performance, stress tolerance, and 
TABLE 1.-Formulation and proximate composition of experimental feeds fed to sunshine bass (based on Brown and Griffin 1993). Natural-source vitamin E (NSVE) was fed at the minimum required level $(22 \mathrm{mg} / 1 \mathrm{X})$ and in multiples of the minimum. The ETH treatment included ethoxyquin. All values are reported as grams per kilogram of dry matter, except where noted.

\begin{tabular}{|c|c|c|c|c|c|c|}
\hline \multirow[b]{2}{*}{ Variable } & \multicolumn{6}{|c|}{ Dietary treatment } \\
\hline & $1 \mathrm{X}$ & $2 X$ & $5 \mathrm{X}$ & $10 \mathrm{X}$ & $100 \mathrm{X}$ & ETH \\
\hline \multicolumn{7}{|l|}{ Ingredient } \\
\hline Menhaden meal ${ }^{\mathrm{a}}$ & 100 & 100 & 100 & 100 & 100 & 100 \\
\hline Casein (vitamin-free) & 350 & 350 & 350 & 350 & 350 & 350 \\
\hline Menhaden ${ }^{\mathrm{a}} /$ tocopherol-stripped canola oil (50:50) & 70 & 70 & 70 & 70 & 70 & 70 \\
\hline Dextrin & 330 & 330 & 330 & 330 & 330 & 330 \\
\hline Carboxymethyl cellulose & 20 & 20 & 20 & 20 & 20 & 20 \\
\hline Vitamin premix ${ }^{\mathrm{b}}$ (vitamin E-free) & 5 & 5 & 5 & 5 & 5 & 5 \\
\hline Mineral premix $\mathrm{x}^{\mathrm{c}}$ & 80 & 80 & 80 & 80 & 80 & 80 \\
\hline Cellulose & 40 & 40 & 40 & 40 & 40 & 40 \\
\hline Choline chloride & 5 & 5 & 5 & 5 & 5 & 5 \\
\hline $\operatorname{NSVE}^{\mathrm{d}}(\mathrm{mg})$ & 22 & 44 & 110 & 220 & 2200 & 22 \\
\hline Ethoxyquin (mg) & 0 & 0 & 0 & 0 & 0 & 300 \\
\hline \multicolumn{7}{|l|}{ Proximate Composition } \\
\hline Dry matter & 765 & 825 & 831 & 811 & 846 & 789 \\
\hline Protein & 443 & 393 & 436 & 437 & 433 & 443 \\
\hline Lipid & 64 & 69 & 67 & 65 & 70 & 65 \\
\hline Ash & 75 & 75 & 76 & 75 & 75 & 76 \\
\hline$\alpha$-tocopheryl acetate $(\mathrm{mg})$ & 31 & 40 & 90 & 243 & 1698 & 59 \\
\hline
\end{tabular}

${ }^{a}$ Omega Protein Corporation, Inc., Houston, Texas.

${ }^{\mathrm{b}}$ Formulated to contain the following per $100 \mathrm{~g}$ of premix: $76.1115 \mathrm{~g}$ of glucose, $8.8000 \mathrm{~g}$ of inositol, $6.0914 \mathrm{~g}$ of ascorbic acid, $3.3000 \mathrm{~g}$ of nicotinic acid, $2.000 \mathrm{~g}$ of calcium pantothenate, $0.9091 \mathrm{~g}$ of menadione sodium bisulfate complex, 0.8800 $\mathrm{g}$ of thiamine hydrochloride, $0.8000 \mathrm{~g}$ of pyroxidine hydrochloride, $0.4400 \mathrm{~g}$ of riboflavin, $0.3200 \mathrm{~g}$ of vitamin A palmitate, $0.2000 \mathrm{~g}$ of folic acid, $0.0800 \mathrm{~g}$ of cyanocobalamin, $0.0600 \mathrm{~g}$ of cholecalciferol, and $0.0080 \mathrm{~g}$ of biotin.

c Formulated to contain the following per $100 \mathrm{~g}$ of premix: $27.55 \mathrm{~g}$ of cellulose, $25.74 \mathrm{~g}$ of calcium carbonate, $24.00 \mathrm{~g}$ of sodium phosphate, $20.00 \mathrm{~g}$ of potassium phosphate, $1.20 \mathrm{~g}$ of sodium chloride, $0.50 \mathrm{~g}$ of magnesium sulfate, $0.20 \mathrm{~g}$ of zinc sulfate, $0.20 \mathrm{~g}$ of ferrous sulfate, $0.20 \mathrm{~g}$ of manganese sulfate, $0.10 \mathrm{~g}$ of aluminum chloride, $0.10 \mathrm{~g}$ of potassium fluoride, $0.10 \mathrm{~g}$ of cupric chloride, $0.05 \mathrm{~g}$ of sodium molybdate, $0.04 \mathrm{~g}$ of sodium selenite, $0.01 \mathrm{~g}$ of potassium iodide, and $0.01 \mathrm{~g}$ of cobalt chloride.

${ }^{\mathrm{d}}$ Archer Daniels Midland Company, Animal Health and Nutrition Division, Decatur, Illinois.

nonspecific immunocompetency of juvenile sunshine bass.

\section{Methods}

Diet preparation and analyses.-Six isocaloric, isonitrogenous, semipurified diets were prepared based on a formulation previously developed for juvenile sunshine bass (Table 1; Brown and Griffin 1993). The feeds were formulated to vary only in antioxidant composition. One control feed was formulated to meet the minimum dietary requirement of sunshine bass as met by NSVE (22 mg of supplemental NSVE/ $\mathrm{kg}$ of feed; treatment 1X; Trushenski and Kohler 2006). A second control feed (ETH) was formulated to contain $22 \mathrm{mg} \mathrm{NSVE} / \mathrm{kg}$ feed and $300 \mathrm{mg}$ ethoxyquin/ $\mathrm{kg}$ feed. Four test feeds were formulated to contain 44, 110, 220 , or $2,200 \mathrm{mg} \mathrm{NSVE} / \mathrm{kg}$ feed (treatments $2 \mathrm{X}, 5 \mathrm{X}$, $10 \mathrm{X}$, and $100 \mathrm{X}$, respectively). The feeds were processed into 3-mm sinking pellets, dried at ambient temperature, and stored frozen $\left(-20^{\circ} \mathrm{C}\right)$ throughout the duration of the study. Proximate analyses of triplicate diet samples were conducted according to standard methods for analysis of animal feeds (AOAC International 1995), confirming diet composition (mean \pm
$\mathrm{SE})$ as $431 \pm 6 \mathrm{~g}$ crude protein $/ \mathrm{kg}, 67.0 \pm 0.6 \mathrm{~g}$ crude lipid $/ \mathrm{kg}, 76.0 \pm 0.2 \mathrm{~g}$ ash $/ \mathrm{kg}$, and $811 \pm 7 \mathrm{~g}$ dry matter $/ \mathrm{kg}$.

Total $\alpha$-tocopheryl acetate concentrations were confirmed via sample saponification-extraction and quantification by high-performance liquid chromatography (HPLC). Sample saponification and extraction procedures were adapted (performance verified with known samples; lipid matrix; 95\% recovery of $\alpha$ tocopheryl acetate) from Bourgeois and Ciba (1988). Briefly, 2-g diet samples were ground into a fine powder and were saponified for $20 \mathrm{~min}$ with $0.5 \mathrm{~mL}$ of iso-octane, $7 \mathrm{~mL}$ of ascorbic acid solution $(0.25 \mathrm{~g}$ of ascorbic acid in $60 \mathrm{~mL}$ of 5:1 ethanol : distilled water), and $1.5 \mathrm{~mL}$ of concentrated potassium hydroxide solution $(50 \mathrm{~g}$ of $\mathrm{KOH}$ in $50 \mathrm{~mL}$ of distilled water) under $\mathrm{N}$ at $120^{\circ} \mathrm{C}$. Samples were centrifuged at $2,750 \times$ gravity $(g)$ for $10 \mathrm{~min}$ at ambient temperature, and the supernatant was filtered by a diatomaceous earth column. The resulting antioxidant extract was evaporated to dryness under $\mathrm{N}_{2}$ and resuspended in isooctane. The resuspended samples were analyzed with a HPLC system and ultraviolet (UV) detector (Shimadzu Corporation, Kyoto, Japan; models LC-10Ai and SPD- 
10AV) equipped with a fused-silica column (4 $\mu \mathrm{m}$, $250.0 \times 4.6 \mathrm{~mm}$; Phenomenex, Inc., Torrance, California; Synergi Hydro-RP) according to the following isocratic elution-detection protocol: 75:25 acetonitrile : methanol mobile phase, $2.0-\mathrm{mL} / \mathrm{min}$ flow rate, 20-min run time at ambient temperature, and UVvisible detection at 280-nm wavelength. Discrepancies between formulated and actual tocopherol content (Table 1) were attributed to small batch size and the diet manufacturing issues raised by the viscosity of the NSVE product used.

Experimental design, feeding trial, and experimental stressor exposure.-A water recirculation system consisting of twenty-four 150-L fiberglass tanks and associated mechanical and biological filtration units was stocked with 18 age-0 sunshine bass per tank (mean $\pm \mathrm{SE}=23.3 \pm 0.5 \mathrm{~g}$; mixed sex; produced inhouse from captive broodstock). The six dietary treatments were each randomly assigned to four replicate tanks. Fish were fed their assigned feeds daily for a total of 8 weeks; feeding rates were adjusted weekly according to apparent satiation.

Temperature, dissolved oxygen (Yellow Springs Instruments, Inc., Yellow Springs, Ohio; Model 55 oxygen meter), and pH (WTW, Weilheim, Germany; Model PH315i handheld $\mathrm{pH}$ meter) were measured daily and maintained at $24.0 \pm 0.5^{\circ} \mathrm{C}, 7.7 \pm 0.2 \mathrm{mg} / \mathrm{L}$, and $7.5 \pm 0.3$, respectively. Alkalinity, ammonia-N, nitrite-N, and nitrate-N were measured weekly (Hach Company, Loveland, Colorado; Model DR/2010 spectrophotometer). All water quality attributes were maintained within ranges suitable for sunshine bass culture (Kohler 2000). Photoperiod was maintained at $12 \mathrm{~h}$ light : $12 \mathrm{~h}$ dark. All methods for culture and husbandry, experimental stressor exposure, euthanasia, and sample collection were conducted under the direction and approval of the Southern Illinois University Institutional Animal Care and Use Committee (protocol number 04-016).

After termination of the feeding trial, surviving fish in each tank were divided into three groups according to experimental stressor exposure: (1) acute, (2) subchronic, and (3) control. To simulate an acute stress event, fish assigned to the first group were chased aggressively with a dip net for $1 \mathrm{~min}$. To simulate a more severe or subchronic stress event, fish in the second group were exposed to the acute stress protocol followed by confinement in a submerged dip net for $1 \mathrm{~h}$. Control groups were not exposed to any experimental stress protocol.

Sample collection and preparation.-After experimental stressor exposure, fish were anesthetized in a 3$\mathrm{mg} / \mathrm{L}$ aqueous solution of Aquacalm (Syndel International, Ltd., Qualicum Beach, British Columbia).
Control fish were anesthetized immediately, whereas acute and subchronic groups were sampled $1 \mathrm{~h}$ after stressor initiation. Once fish were sufficiently sedated, individuals were weighed (nearest $0.1 \mathrm{~g}$ ) and blood samples were collected from the caudal vasculature in lithium heparin-treated blood collection tubes (Becton, Dickinson and Co., Franklin Lakes, New Jersey; Vacutainer). Whole-blood samples were centrifuged $\left(700 \times g\right.$ for $10 \mathrm{~min}$ at $\left.4^{\circ} \mathrm{C}\right)$, and resulting plasma samples were pooled according to dietary-stress experimental group within tanks and stored frozen $\left(-80^{\circ} \mathrm{C}\right)$ until subsequent analysis. Immediately after blood collection, fish were euthanized by cranial pithing and then were dissected. Muscle and kidney tissue samples were collected from all individuals, and livers and intraperitoneal (IP) fat masses were removed from control fish and weighed to the nearest $0.1 \mathrm{~g}$. Muscle samples were packaged in sterile polyethylene bags (NASCO, Fort Atkinson, Wisconsin; Whirl-Pak) and stored in the same manner as plasma samples. Pooled renal samples were suspended in ice-cold Leibovitz L-15 medium (BioWhittaker, Walkersville, Maryland) supplemented with heparin sodium (10 units/mL; Acros Organics, Geel, Belgium), HyQ penicillin-streptomycin solution $(100 \mu \mathrm{g}$ of penicillin +100 units of streptomycin/mL; Hyclone, Logan, Utah), and $2 \%$ sterile fetal bovine serum (BioWhittaker), and were held refrigerated $\left(4^{\circ} \mathrm{C}\right)$ before macrophage collection via the discontinuous Percoll (Amersham Biosciences, Piscataway, New Jersey) separation method of Garduño and Kay (1994).

Production performance.-Survival was calculated for each tank, and percentage weight gain, hepatosomatic index (HSI; [liver weight/whole body weight] $\times$ 100), liposomatic index (LSI; [IP fat weight/whole body weight] $\times 100$ ), and feed conversion ratio $(\mathrm{FCR}$; dry matter weight of food/wet weight gained) were calculated per individual and then averaged by tank. After tissue lyophilization and pulverization, muscle tocopherols were extracted according to the two-phase extraction method of Huo et al. (1996) and quantified according to the HPLC methodology outlined above for $\alpha$-tocopheryl acetate determination of feed samples. To estimate postslaughter fillet oxidative stability, muscle samples were analyzed for the presence of peroxides and aldehydes with Peroxysafe and Aldesafe colorimetric assay kits (Saftest, Inc., Phoenix, Arizona) shortly after termination of the study (1 month; short term) and after 6 months of frozen storage (long term). All peroxide-aldehyde concentrations were standardized for fillet lipid content (Folch et al. 1957).

Stress physiology.-Cortisol was isolated from plasma samples with use of an enzyme immunoassay (DRG International, Inc., Mountainside, New Jersey) 
and quantified spectrophotometrically (Thermo Fisher Scientific, Inc., Waltham, Massachusetts; Multiskan Plus) according to the manufacturer's instructions. Plasma glucose concentrations were measured with a human diabetic testing kit (Abbott Laboratories, Abbott Park, Illinois; Freestyle glucose monitoring kit). Plasma osmolality was determined with a vapor pressure osmometer (Wescor, Inc., Logan, Utah; Model 5100C).

Nonspecific immunity.-Macrophage monolayer cultures were prepared in 96-well microplates by administering $200 \mu \mathrm{L}$ of the macrophage-enriched suspensions $\left(5 \times 10^{3}\right.$ viable cells $\left./ \mathrm{mL}\right)$ to each well and incubating for $2 \mathrm{~h}$ at ambient temperatures to facilitate cell attachment. Macrophage respiratory burst activity was subsequently measured according to the ferricytochrome-c reduction protocol of Secombes (1990). After addition of a ferricytochrome-c-phorbol myristate acetate solution to trigger respiratory burst, absorbance $(\lambda=590 \mathrm{~nm})$ was measured every $30 \mathrm{~s}$ for a total of $1 \mathrm{~h}$ (Multiskan Plus). Data from duplicate wells were averaged, and the maximum reaction rate $\left(V_{\max }\right)$ of superoxide generation was reported as milli-optical density units per minute.

Macrophage bactericidal activity was measured on stock cultures of Micrococcus lysodeiktus according to a protocol adapted from Peddie et al. (2002). Macrophage monolayer microplates prepared as previously described were inoculated with stock $M$. lysodeiktus culture in tryptic soy broth (TSB). After incubation at ambient temperature for 0 (T0) or 5 (T5) $\mathrm{h}$, the plates were washed to remove the bacterial suspension, and bactericidal activity was terminated by the addition of $50 \mu \mathrm{L}$ of distilled water. Aliquots (100 $\mu \mathrm{L}$ ) of TSB were added to the wells, and surviving bacteria (phagocytosed but not lysed) were allowed to proliferate at ambient temperature overnight. Aliquots of MTT solution (3-[4,5-dimethylthiazol]-2,5-diphenyltetrazolium bromide; Sigma-Aldrich, Inc., St. Louis, Missouri) at $5 \mathrm{mg} \mathrm{MTT} / \mathrm{mL}$ distilled water were added to the wells, and absorbance $(\lambda=590 \mathrm{~nm})$ was determined. Using averages from duplicate wells, bactericidal activity was calculated as $\left(\lambda_{\mathrm{T} 5} / \lambda_{\mathrm{T} 0}\right) \times$ 100 and reported as percentage bacterial mortality.

Plasma lysozyme activity was estimated with a $M$. lysodeiktus lysis assay based on the spectrophotometric method of Obach et al. (1993) modified for microplate wells. Aliquots $(10 \mu \mathrm{L})$ of whole plasma were added to wells containing $190 \mu \mathrm{L}$ of $M$. lysodeiktus stock culture. Absorbance $(\lambda=450 \mathrm{~nm})$ was measured immediately and every $15 \mathrm{~s}$ thereafter for a total of 2 min (Multiskan Plus). Lysozyme activity was calculated from $M$. lysodeiktus lysis ( $V_{\text {max }}$; absorbance units/ min) and reported in enzyme units per milliliter of plasma.

Statistical analyses.-Although multiple individual fish were sampled from each tank, replicate tanks served as the experimental units for all statistical analyses $(N=4$ replicates/treatment). Production performance and fillet tocopherol data collected before experimental stressor procedures were analyzed by one-way analysis of variance (ANOVA) within the mixed-model framework of the Statistical Analysis System version 9.1 to determine whether differences existed among dietary treatment groups. All remaining data were subjected to two-way ANOVA within the mixed-model framework to determine whether differences existed among treatment groups based on all the response variables and to test for interaction among the stressor and dietary treatments. For variables exhibiting significant differences, CONTRAST statements were used to compare means. In all cases, differences were considered significant at $P$-values of 0.05 or less.

\section{Results}

We observed no immediate immunosuppressive effects of stress; however, stressor exposure resulted in increased vulnerability of fillet tissue to oxidative degradation. Oxidation product concentrations were significantly altered by stressor exposure after shortterm frozen storage (Table 2); subchronic stress was associated with significantly higher aldehyde and lower peroxide concentrations relative to the control. Providing more NSVE in the diet augmented fillet tocopherol content (Table 3)-linearly, in the case of $\alpha$-tocopherol (Figure 1). Survival (mean $\pm \mathrm{SE}=93.4 \pm 1.7 \%$ ), weight gain $(280 \pm 4 \%)$, FCR (1.69 \pm 0.02$)$, HSI (1.42 \pm 0.03$)$, and LSI (2.48 \pm 0.04$)$ were not significantly affected by dietary or stressor treatments (Table 3). No dietary-stressor treatment interactions were observed for any of the production performance characteristics.

Plasma cortisol, glucose, and osmolality were significantly affected by exposure to the experimental stressors (Table 4). Cortisol concentrations increased significantly with stressor severity. Plasma glucose concentrations were higher in stressor-exposed groups than in control groups; however, acute and subchronic groups were not significantly different from one another. Plasma osmolality was significantly reduced in the subchronic group relative to control and acute stressor groups. Diet and diet $\times$ stress effects on stress physiology were nonsignificant.

No significant differences in lysozyme activity, macrophage respiratory burst, or bactericidal activity were observed with respect to stressor or dietary treatments (Table 5), and no significant interactions 
TABLE 2.- Sunshine bass fillet oxidation byproduct concentrations after short- and long-term frozen storage by dietary and stress treatments. Dietary treatments were natural-source vitamin E (NSVE) at the minimum required level (22 mg/kg; $1 \mathrm{X})$ and in multiples of the minimum. The ETH treatment included $300 \mathrm{mg}$ of ethoxyquin $/ \mathrm{kg}$ of feed and $22 \mathrm{mg} \mathrm{NSVE} / \mathrm{kg}$. Least-squares means $( \pm \mathrm{SE})$ for each treatment factor combination are shown in normal text; means across stress and dietary treatment factors are shown in italics. The $P$-values for each response variable and their interaction are also provided. Means with different letters are significantly different $(P<0.05)$.

\begin{tabular}{|c|c|c|c|c|c|c|c|c|}
\hline \multirow{2}{*}{$\begin{array}{c}\text { Fillet } \\
\text { storage } \\
\text { duration }\end{array}$} & \multirow[b]{2}{*}{ Variable } & \multirow{2}{*}{$\begin{array}{c}\text { Stress } \\
\text { treatment }^{\mathrm{a}}\end{array}$} & \multicolumn{6}{|c|}{ Dietary treatment } \\
\hline & & & $1 \mathrm{X}$ & $2 \mathrm{X}$ & $5 X$ & $10 \mathrm{X}$ & $100 \mathrm{X}$ & ETH \\
\hline \multirow[t]{6}{*}{1 month } & Peroxides $(\mathrm{mEq} / \mathrm{kg})$ & Control & $0.50 \pm 0.14$ & $0.47 \pm 0.14$ & $0.28 \pm 0.14$ & $0.51 \pm 0.14$ & $0.54 \pm 0.14$ & $0.52 \pm 0.14$ \\
\hline & & Subchronic & $0.00 \pm 0.14$ & $0.00 \pm 0.14$ & $0.00 \pm 0.14$ & $0.00 \pm 0.14$ & $0.00 \pm 0.14$ & $0.00 \pm 0.14$ \\
\hline & & Mean & 0.25 & 0.23 & 0.14 & 0.25 & 0.27 & 0.26 \\
\hline & Aldehydes (mg/kg) & Control & $0.00 \pm 0.12$ & $0.06 \pm 0.12$ & $0.04 \pm 0.12$ & $0.00 \pm 0.12$ & $0.00 \pm 0.12$ & $0.00 \pm 0.12$ \\
\hline & & Subchronic & $0.20 \pm 0.12$ & $0.27 \pm 0.12$ & $0.34 \pm 0.12$ & $0.28 \pm 0.12$ & $0.25 \pm 0.12$ & $0.63 \pm 0.12$ \\
\hline & & Mean & 0.10 & 0.16 & 0.19 & 0.14 & 0.12 & 0.32 \\
\hline \multirow[t]{6}{*}{6 months } & Peroxides $(\mathrm{mEq} / \mathrm{kg})$ & Control & $0.00 \pm 0.28$ & $0.00 \pm 0.28$ & $0.00 \pm 0.28$ & $0.00 \pm 0.28$ & $0.00 \pm 0.28$ & $0.00 \pm 0.28$ \\
\hline & & Subchronic & $0.00 \pm 0.28$ & $0.91 \pm 0.28$ & $0.00 \pm 0.28$ & $0.00 \pm 0.28$ & $0.40 \pm 0.28$ & $0.09 \pm 0.28$ \\
\hline & & Mean & 0.00 & 0.46 & 0.00 & 0.00 & 0.20 & 0.04 \\
\hline & Aldehydes (mg/kg) & Control & $3.09 \pm 0.89$ & $1.39 \pm 0.89$ & $2.48 \pm 0.89$ & $0.96 \pm 0.89$ & $1.58 \pm 0.89$ & $2.03 \pm 0.89$ \\
\hline & & Subchronic & $2.71 \pm 0.89$ & $1.63 \pm 0.89$ & $0.20 \pm 0.89$ & $2.24 \pm 0.89$ & $0.50 \pm 0.89$ & $2.14 \pm 0.89$ \\
\hline & & Mean & 2.90 & 1.51 & 1.34 & 1.60 & 1.04 & 2.08 \\
\hline
\end{tabular}

${ }^{a}$ Subchronic stress event involved confinement in a submerged dip net for $1 \mathrm{~h}$.

among the treatments were observed for these variables.

\section{Discussion}

In this study, sunshine bass fillet tocopherol composition tended to reflect dietary NSVE content; significantly increased levels of deposition were associated with the 100X treatment level. Fillet $\gamma$ tocopherol concentration was also increased at the highest level of NSVE supplementation, probably because minute amounts of this compound occurred as an impurity in the NSVE product used. Linear regressions of mean fillet $\alpha$-tocopherol concentrations (standardized to fillet dry matter) versus as-fed dietary vitamin $\mathrm{E}$ concentration revealed diet-to-fillet transfer greater than reported for SYNE in other aquatic species (Stéphan et al. 1995; Ruff et al. 2002; Chaiyapechara et al. 2003). The increased potency of NSVE is associated with superior binding of $R R R$ - $\alpha$-tocopherol to hepatic $\alpha$-tocopherol transport protein ( $\alpha$-TTP) and therefore greater retention of $R R R$ - $\alpha$-tocopherol compared with its racemates or other tocopherol isomers (Stone and Papas 2003). The $\alpha$-TTP facilitates selective uptake of $R R R$ - $\alpha$-tocopherol from hepatic circulation and may enhance systemic trafficking and tissue deposition of $R R R$ - $\alpha$-tocopherol (Blatt et al. 2001). Although $\alpha$-TTP has not been isolated from a teleost model, apparent patterns of discriminatory tocopherol trafficking in sunshine bass and Atlantic salmon Salmo salar (Hamre and Lie 1997) are similar to those observed in mammalian models. It is reasonable to assume the increased biological activity (Trushenski and Kohler 2006) and the high level of tissue retention we observed for NSVE is related to the affinity of $\alpha$-TTP for $R R R$ - $\alpha$-tocopherol.

As the secondary byproducts of oxidation, measurable levels of aldehydes indicate fillet oxidation has surpassed the initial phase of peroxide formation. Thus, elevated aldehyde fillet content among subchronic stressor-exposed fish suggests an advanced state of oxidative degradation after short-term storage. Stressor exposure, particularly preslaughter, has long been associated with reduced flesh quality. Severely stressful harvesting procedures result in mechanical damage (i.e., scaling and bruising), reduced fillet $\mathrm{pH}$ and energy content, and rapid onset of rigor (Poli et al. 2005). Our results suggest even comparatively benign procedures can negatively affect oxidative stability of sunshine bass fillets during short-term storage. Tocopherols prevent free radical oxidation of lipids and fatty acids in vivo (Bell et al. 2000); postslaughter, they can reduce rates of oxidation and lengthen shelf life of fresh or frozen fillets (Gatta et al. 2000; Ruff et al. 2002; Hamre et al. 2004). Tissue $\alpha$-tocopherol content and oxidative stability have been enhanced via dietary supplementation with SYNE in sunshine bass (Kocabas and Gatlin 1999), rainbow trout Oncorhynchus mykiss (Chaiyapechara et al. 2003), European seabass Dicentrarchus labrax (Gatta et al. 2000), Atlantic salmon (Hamre et al. 1998, 2004; Scaife et al. 2000), Atlantic halibut Hippoglossus hippoglossus (Ruff et al. 2002, 2004), and turbot Scophthalmus maximus (Ruff et al. 2003, 2004). Although no significant differences were noted after long-term storage, fillet aldehydes numerically decreased with increasing dietary NSVE but not with ethoxyquin. All fillets were kept frozen through- 
TABLE 2.-Extended.

\begin{tabular}{llccc}
\hline $\begin{array}{c}\text { Fillet } \\
\text { storage } \\
\text { duration }\end{array}$ & Means & Diet & Stress & Diet $\times$ stress \\
\hline \cline { 2 - 4 } 1 month & $\begin{array}{l}0.47 \mathrm{z} \\
0.00 \mathrm{y}\end{array}$ & 0.94 & $<0.01$ & 0.94 \\
& $0.02 \mathrm{y}$ & 0.54 & $<0.01$ & 0.50 \\
& $0.33 \mathrm{z}$ & & & \\
6 months & 0.00 & 0.53 & 0.17 & 0.53 \\
& 0.23 & & & \\
& 1.92 & 0.39 & 0.50 & 0.48 \\
& 1.57 & & & \\
& & & &
\end{tabular}

out the storage period, minimizing overall oxidation and potentially masking the influence of fillet antioxidant content. Had the fillets been exposed to warmer temperatures, freeze-thaw cycles, or both, the magnitude of oxidation and perhaps the protective effect of increased fillet tocopherol would have been more pronounced.

We were unable to resolve any significant immunological effects of stress; however, nonsignificant reductions in bactericidal and lysozyme activities were noted in association with stressor exposure. These reductions in activity agree with the well-established relationship between stress and immunosuppression (Barton and Iwama 1991; Bly et al. 1997; Magnadóttir 2006); the lack of significance we observed is probably an artifact of our sampling protocols. Collection of tissue samples $1 \mathrm{~h}$ after stressor exposure allowed for development of the generalized adaptation syndrome, as indicated by the elevated plasma cortisol and glucose concentrations and depressed osmolality (Bar- ton and Iwama 1991; Mommsen et al. 1999) measured in the experimentally stressed animals. Stress-related immunosuppression may take longer to develop; thus, our sampling window may have been too narrow to capture any immunological perturbations caused by stressors employed.

Super-requirement levels of vitamin E have elicited positive immunological effects in a variety of aquatic species, though supplemental vitamin $\mathrm{E}$ has been reported to have little-to-no effect on immune response or disease resistance of sunshine bass (Sealey and Gatlin 2002a, 2002b, 2002c). Elevated levels of vitamin $\mathrm{E}$ were accompanied by an increase in phagocytic activity in rainbow trout (Clerton et al. 2001) and gilthead seabream Sparus aurata (Mulero et al. 1998; Ortuño et al. 2000). Enhanced lysozyme activity has been reported for malabar grouper Epinephelus malabaricus (Lin and Shiau 2005), rainbow trout (Kiron et al. 2004), and Indian major carp Labeo rohita (Sahoo and Mukherjee 2002) fed increasing levels of vitamin E. Increased oxidative burst has been reported in association with vitamin $\mathrm{E}$ supplementation, but these studies typically observed enhanced responses in conjunction with increased levels of other micro- or macronutrients, such as vitamin C (Mulero et al. 1998; Wahli et al. 1998; Sealey and Gatlin 2002b) or lipid (Lin and Shiau 2005). Statistically significant effects were not reported in all studies, and the variability of the data was often cited as a limitation. We also noted high individual-toindividual variation within our immunological data, which may have obscured patterns of dietary effect. The reported potency of NSVE relative to SYNE suggests that it may possess greater immunomodulatory activity, but experimentation directed at reducing the confounding effects of individual variability is needed to fully address this hypothesis.

Advances in stereochemistry and the analytical capacity to separate and define specific vitamin $\mathrm{E}$ isomers and stereoisomers have vastly improved our

TABLE 3.-Production performance and fillet tocopherol content of sunshine bass fed natural-source vitamin E (NSVE) at the minimum required level $(22 \mathrm{mg} / \mathrm{kg}$ of feed; $1 \mathrm{X})$ and in multiples of the minimum. The ETH treatment included $300 \mathrm{mg}$ of ethoxyquin $/ \mathrm{kg}$ of feed and $22 \mathrm{mg} \mathrm{NSVE} / \mathrm{kg}$. Within a row, means with common letters are not significantly different $(P>0.05)$.

\begin{tabular}{|c|c|c|c|c|c|c|c|}
\hline \multirow[b]{2}{*}{ Variable } & \multirow[b]{2}{*}{ SE } & \multicolumn{6}{|c|}{ Dietary treatment } \\
\hline & & $1 \mathrm{X}$ & $2 X$ & $5 X$ & $10 \mathrm{X}$ & $100 \mathrm{X}$ & ETH \\
\hline Survival (\%) & 3.9 & 90.3 & 98.6 & 100.0 & 87.4 & 90.0 & 94.4 \\
\hline Weight gain $(\%)$ & 9.3 & 292.2 & 290.2 & 284.5 & 258.0 & 281.2 & 272.5 \\
\hline Feed conversion ratio & 0.04 & 1.32 & 1.35 & 1.38 & 1.35 & 1.45 & 1.32 \\
\hline Hepatosomatic index & 0.07 & 1.36 & 1.35 & 1.48 & 1.41 & 1.42 & 1.49 \\
\hline Liposomatic index & 0.21 & 2.29 & 2.42 & 2.57 & 2.13 & 3.10 & 2.34 \\
\hline Fillet $\alpha$-tocopherol concentration ( $\mu \mathrm{g} / \mathrm{g}$, dry tissue) & 70.4 & $35.8 \mathrm{y}$ & $81.7 \mathrm{y}$ & $105.0 \mathrm{y}$ & $213.0 \mathrm{y}$ & $1,148.4 \mathrm{z}$ & $126.0 \mathrm{y}$ \\
\hline Fillet $\gamma$-tocopherol concentration ( $\mu \mathrm{g} / \mathrm{g}$, dry tissue) & 1.1 & $1.4 \mathrm{y}$ & $1.7 \mathrm{y}$ & $1.5 \mathrm{y}$ & $2.1 \mathrm{y}$ & $8.4 \mathrm{z}$ & $2.1 \mathrm{y}$ \\
\hline Fillet $\delta$-tocopherol concentration $(\mu \mathrm{g} / \mathrm{g}$, dry tissue) & 0.5 & 0.4 & 0.5 & 0.8 & 0.8 & 2.5 & 0.6 \\
\hline
\end{tabular}




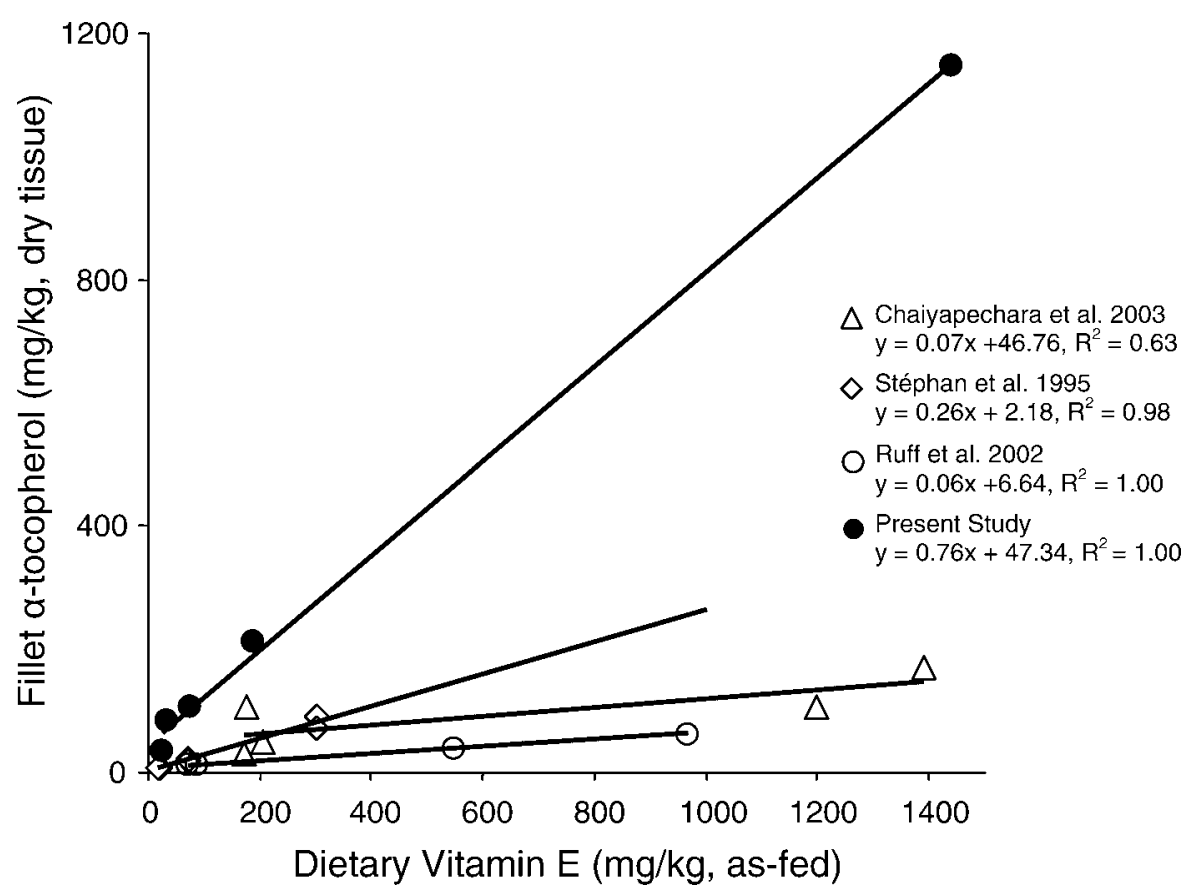

FIGURE 1.-Sunshine bass fillet incorporation of $\alpha$-tocopherol according to dietary supplementation with vitamin E. Closed circles represent mean fillet $\alpha$-tocopherol concentrations resulting from dietary supplementation with natural-source vitamin $\mathrm{E}$ in this study. Open symbols represent mean fillet $\alpha$-tocopherol as reported in Stéphan et al. (1995), Ruff et al. (2002), and Chaiyapechara et al. (2003) as a result of synthetic vitamin E supplementation. Lines represent best-fit linear regressions through the respective means.

understanding of the specific roles of these compounds, though many questions remain to be answered. Regardless, the importance of stereoisomeric composition in determining the efficacy of vitamin $\mathrm{E}$ supplements for human and animal nutrition is becoming increasingly clear, and $R R R$ - $\alpha$-tocopherol has emerged as a highly potent micronutrient source. Our results suggest that stress exposure reduces

TABLE 4.- Physiological stress response variables measured in sunshine bass subjected to different dietary and stress treatments. Dietary treatments were vitamin E (NSVE) at the minimum required level $(22 \mathrm{mg} / \mathrm{kg}$ of feed; $1 \mathrm{X})$ and in multiples of the minimum. The ETH treatment included $300 \mathrm{mg}$ of ethoxyquin/ $\mathrm{kg}$ feed and $22 \mathrm{mg} \mathrm{NSVE} / \mathrm{kg}$. Least-squares means ( \pm SE) for each treatment factor combination are shown in normal text; means across stress and dietary treatment factors are shown in italics. The $P$-values for each response variable and their interaction are also provided. Means with different letters are not significantly different $(P<0.05)$.

\begin{tabular}{|c|c|c|c|c|c|c|c|c|c|c|c|}
\hline \multirow[b]{2}{*}{ Variable } & \multirow{2}{*}{$\begin{array}{c}\text { Stress } \\
\text { treatment }^{\mathrm{a}}\end{array}$} & \multicolumn{6}{|c|}{ Dietary treatment } & \multirow[b]{2}{*}{ Mean } & \multicolumn{3}{|c|}{ Two-way ANOVA $P$} \\
\hline & & $1 \mathrm{X}$ & $2 X$ & $5 X$ & $10 \mathrm{X}$ & $100 \mathrm{X}$ & ETH & & Diet & Stress & Diet $\times$ stress \\
\hline \multirow{4}{*}{$\begin{array}{l}\text { Plasma cortisol } \\
\text { (ng/mL) }\end{array}$} & Control & $36 \pm 31$ & $53 \pm 31$ & $38 \pm 31$ & $70 \pm 31$ & $36 \pm 31$ & $50 \pm 31$ & $47 \mathrm{x}$ & \multirow[t]{4}{*}{0.74} & \multirow[t]{4}{*}{$<0.01$} & \multirow[t]{4}{*}{0.51} \\
\hline & Acute & $141 \pm 31$ & $161 \pm 31$ & $225 \pm 31$ & $88 \pm 31$ & $170 \pm 31$ & $147 \pm 31$ & $155 \mathrm{y}$ & & & \\
\hline & Subchronic & $240 \pm 31$ & $222 \pm 31$ & $249 \pm 31$ & $240 \pm 31$ & $218 \pm 31$ & $216 \pm 31$ & $231 \mathrm{z}$ & & & \\
\hline & Mean & 139 & 145 & 171 & 132 & 141 & 138 & & & & \\
\hline \multirow{4}{*}{$\begin{array}{l}\text { Plasma glucose } \\
\text { (mg/dL) }\end{array}$} & Control & $128 \pm 28$ & $141 \pm 28$ & $145 \pm 28$ & $192 \pm 28$ & $133 \pm 28$ & $158 \pm 28$ & $149 \mathrm{y}$ & \multirow[t]{4}{*}{0.76} & \multirow[t]{4}{*}{$<0.01$} & \multirow[t]{4}{*}{0.63} \\
\hline & Acute & $291 \pm 28$ & $342 \pm 28$ & $341 \pm 28$ & $301 \pm 32$ & $364 \pm 28$ & $366 \pm 28$ & $334 \mathrm{z}$ & & & \\
\hline & Subchronic & $364 \pm 28$ & $369 \pm 28$ & $386 \pm 28$ & $356 \pm 28$ & $345 \pm 28$ & $360 \pm 28$ & $363 \mathrm{z}$ & & & \\
\hline & Mean & 261 & 284 & 290 & 283 & 280 & 294 & & & & \\
\hline \multirow{4}{*}{$\begin{array}{l}\text { Plasma osmolality } \\
\qquad(\mathrm{mOsm} / \mathrm{kg})\end{array}$} & Control & $390 \pm 21$ & $439 \pm 21$ & $427 \pm 21$ & $426 \pm 21$ & $376 \pm 21$ & $388 \pm 21$ & $408 \mathrm{z}$ & \multirow[t]{4}{*}{0.39} & \multirow[t]{4}{*}{0.02} & \multirow[t]{4}{*}{0.64} \\
\hline & Acute & $390 \pm 21$ & $417 \pm 21$ & $428 \pm 21$ & $382 \pm 24$ & $428 \pm 21$ & $407 \pm 21$ & $408 \mathrm{z}$ & & & \\
\hline & Subchronic & $371 \pm 21$ & $382 \pm 21$ & $386 \pm 21$ & $358 \pm 21$ & $395 \pm 21$ & $372 \pm 21$ & $377 \mathrm{y}$ & & & \\
\hline & Mean & 384 & 412 & 414 & 389 & 400 & 389 & & & & \\
\hline
\end{tabular}

${ }^{a}$ Acute stress even involved aggressive chasing with a dip net for $1 \mathrm{~min}$. Subchronic stress event involved confinement in a submerged dip net for $1 \mathrm{~h}$. 
TABLE 5.-Nonspecific immune variables in sunshine bass subjected to different dietary and stress treatments. Dietary treatments were vitamin E (NSVE) at the minimum required level $(22 \mathrm{mg} / \mathrm{kg}$ of feed) and in multiples of the minimum. The ETH treatment included $300 \mathrm{mg}$ of ethoxyquin $/ \mathrm{kg}$ of feed and $22 \mathrm{mg} \mathrm{NSVE} / \mathrm{kg}$. Least-squares means ( $\pm \mathrm{SE}$ ) for each treatment factor combination are shown in normal text; means across stress and dietary treatment factors are shown in italics. The $P$-values for each response variable and their interaction are provided; no difference was noted for any variable.

\begin{tabular}{|c|c|c|c|c|c|c|c|c|c|c|c|}
\hline \multirow[b]{3}{*}{ Variable } & \multirow{3}{*}{$\begin{array}{c}\text { Stress } \\
\text { treatment }\end{array}$} & \multirow{2}{*}{\multicolumn{6}{|c|}{ Dietary treatment }} & \multirow[b]{3}{*}{ Mean } & \multicolumn{3}{|c|}{ Two-way ANOVA $P$} \\
\hline & & & & & & & & & & & \\
\hline & & $1 \mathrm{X}$ & $2 \mathrm{X}$ & $5 \mathrm{X}$ & $10 \mathrm{X}$ & $100 \mathrm{X}$ & ETH & & Diet & Stress & stress \\
\hline \multirow{4}{*}{$\begin{array}{l}\text { Respiratory burst } \\
\text { activity }\left(V_{\max }\right. \\
\text { milli-optical } \\
\text { density units/min) }\end{array}$} & Control & $3.4 \pm 0.9$ & $2.5 \pm 0.8$ & $2.5 \pm 0.8$ & $2.0 \pm 0.8$ & $3.5 \pm 0.8$ & $2.0 \pm 0.8$ & 2.6 & \multirow[t]{4}{*}{0.75} & \multirow[t]{4}{*}{0.98} & \multirow[t]{4}{*}{0.50} \\
\hline & Acute & $2.8 \pm 0.8$ & $2.5 \pm 0.8$ & $2.2 \pm 0.8$ & $4.2 \pm 0.8$ & $2.0 \pm 0.8$ & $2.5 \pm 0.8$ & 2.7 & & & \\
\hline & Subchronic & $4.0 \pm 0.8$ & $3.0 \pm 0.8$ & $2.2 \pm 0.8$ & $2.3 \pm 1.1$ & $2.5 \pm 0.8$ & $2.2 \pm 0.8$ & 2.7 & & & \\
\hline & Mean & 3.4 & 2.7 & 2.3 & 2.8 & 2.7 & 2.3 & & & & \\
\hline \multirow{4}{*}{$\begin{array}{l}\text { Bactericidal activity } \\
\text { (\% mortality) }\end{array}$} & Control & $22.0 \pm 6.7$ & $26.5 \pm 5.8$ & $4.8 \pm 5.8$ & $0.0 \pm 5.8$ & $10.2 \pm 5.8$ & $5.2 \pm 5.8$ & 11.4 & \multirow[t]{4}{*}{0.09} & \multirow[t]{4}{*}{0.26} & \multirow[t]{4}{*}{0.25} \\
\hline & Acute & $7.3 \pm 6.7$ & $14.5 \pm 5.8$ & $0.5 \pm 5.8$ & $4.8 \pm 5.8$ & $5.5 \pm 5.8$ & $6.5 \pm 5.8$ & 6.5 & & & \\
\hline & Subchronic & $3.0 \pm 5.8$ & $4.8 \pm 5.8$ & $0.0 \pm 5.8$ & $11.0 \pm 8.2$ & $18.0 \pm 5.8$ & $1.5 \pm 5.8$ & 6.4 & & & \\
\hline & Mean & 10.8 & 15.3 & 1.8 & 5.2 & 11.2 & 4.4 & & & & \\
\hline \multirow{4}{*}{$\begin{array}{l}\text { Plasma lysozyme } \\
\text { activity (enzyme } \\
\text { units } / \mathrm{mL} \text { ) }\end{array}$} & Control & $2.8 \pm 2.6$ & $3.0 \pm 2.6$ & $3.2 \pm 2.6$ & $2.8 \pm 2.6$ & $4.0 \pm 2.6$ & $13.7 \pm 2.6$ & 4.9 & \multirow[t]{4}{*}{0.51} & \multirow[t]{4}{*}{0.66} & \multirow[t]{4}{*}{0.42} \\
\hline & Acute & $3.5 \pm 2.6$ & $4.0 \pm 2.6$ & $4.8 \pm 2.6$ & $3.6 \pm 2.6$ & $3.7 \pm 2.6$ & $3.6 \pm 2.6$ & 3.8 & & & \\
\hline & Subchronic & $2.6 \pm 2.6$ & $3.2 \pm 2.6$ & $5.7 \pm 2.6$ & $3.7 \pm 2.6$ & $3.5 \pm 2.6$ & $3.2 \pm 2.6$ & 3.6 & & & \\
\hline & Mean & 3.0 & 3.4 & 4.5 & 3.4 & 3.7 & 6.8 & & & & \\
\hline
\end{tabular}

a Acute stress event involved aggressive chasing with a dip net for $1 \mathrm{~min}$. Subchronic stress event involved confinement in a submerged dip net for $1 \mathrm{~h}$.

postslaughter fillet oxidative stability; however, providing $R R R$ - $\alpha$-tocopherol as NSVE in excess of the dietary requirement may offer some protection against reductions in shelf life of aquaculture products. The particular roles of the vitamin $\mathrm{E}$ isomers and stereoisomers, specifically the unique functionality of $R R R$ - $\alpha$-tocopherol, may warrant a reevaluation of vitamin $\mathrm{E}$ as a micronutrient and the relative suitability of NSVE and SYNE preparations as dietary supplements. As an antioxidant and mediator of various physiological processes, $R R R$ - $\alpha$-tocopherol merits additional investigation to further elucidate its role in modulating critical biological functions in aquatic livestock.

\section{Acknowledgments}

We thank Archer Daniels Midland Company (Decatur, Illinois) for providing D-alpha, the NSVE product used in this study, and Omega Protein Corporation, Inc. (Houston, Texas), for providing Special Select menhaden meal used in the diets. We also thank Angela Merkel, Heidi Lewis, Andrew Coursey, Adam Jarosinski, and Anita Kelly for their help with data collection and Ryan Lane for his advice in statistical analysis. This research was conducted by the first author as part of a dissertation to partially meet the requirements for a Doctor of Philosophy degree in the Department of Zoology, Southern Illinois University Carbondale. The material presented is based on work supported by the National Science Foundation under grant number 0227925 and Sea Grant under grant number 6-23437. Any opinions, findings, and conclusions or recommendations expressed in this manuscript are those of the authors and do not necessarily reflect the views of the National Science Foundation or Sea Grant.

\section{References}

AOAC International. 1995. Official methods of analysis, 16th edition. AOAC International, Washington, D.C.

Barton, B. A., and G. K. Iwama. 1991. Physiological changes in fish from stress in aquaculture with emphasis on the response and effects of corticosteroids. Annual Review of Fish Diseases 1:2-26.

Bell, J. G., J. McEvoy, D. R. Tocher, and J. R. Sargent. 2000. Depletion of alpha-tocopherol and astaxanthin in Atlantic salmon (Salmo salar) affect autoxidative defense and fatty acid metabolism. Journal of Nutrition 130:18001808.

Blatt, D. H., S. W. Leonard, and M. G. Traber. 2001. Vitamin E kinetics and the function of tocopherol regulatory proteins. Nutrition 17:799-805.

Blazer, V. S., and R. E. Wolke. 1984. The effects of $\alpha$ tocopherol on the immune response and non-specific resistance factors of rainbow trout (Salmo gairdneri Richardson). Aquaculture 37:1-9.

Bly, J. E., S. M. Quiniou, and L. W. Clem. 1997. Environmental effects on fish immune mechanisms. Developments in Biological Standards 90:33-43.

Bourgeois, C. F., and N. Ciba. 1988. Disposable cartridge extraction of retinol and alpha-tocopherol from fatty samples. Journal of the Association of Official Analytical Chemists 71:12-15.

Bowry, V. W., and R. Stocker. 1993. Vitamin E on the radical-initiated oxidation of human low-density lipoprotein. Journal of the American Chemical Society 115:6029-6044.

Brigelius-Flohé, R., and M. G. Traber. 1999. Vitamin E: function and metabolism. FASEB (Federation of 
American Societies for Experimental Biology) Journal 13:1145-1155.

Brown, P. B., and M. E. Griffin. 1993. Experimental and practical diet evaluations with juvenile hybrid striped bass. Journal of the World Aquaculture Society 24:80 89.

Burton, G. W., M. G. Traber, R. V. Acuff, D. N. Walters, H. Kayden, L. Hughes, and K. U. Ingold. 1998. Human plasma and tissue $\alpha$-tocopherol concentrations in response to supplementation with deuterated natural and synthetic vitamin E. American Journal of Clinical Nutrition 67:669-684.

Chaiyapechara, S., M. T. Casten, R. W. Hardy, and F. M. Dong. 2003. Fish performance, fillet characteristics, and health assessment index of rainbow trout (Oncorhynchus mykiss) fed diets containing adequate and high concentrations of lipid and vitamin E. Aquaculture 219:715738.

Clerton, P., D. Troutaud, V. Verlhac, J. Gabaudan, and P. Deschaux. 2001. Dietary vitamin E and rainbow trout (Oncorhynchus mykiss) phagocyte functions: effect on gut and on head kidney leucocytes. Fish and Shellfish Immunology 11:1-13.

Erickson, K. L., E. A. Medina, and N. E. Hubbard. 2000. Micronutrients and innate immunity. Journal of Infectious Diseases 182:S5-S10.

Fletcher, T. C. 1997. Dietary effects on stress and health. Pages 223-246 in G. K. Iwana, A. D. Pickering, J. P. Sumpter, and C. B. Schreck, editors. Fish stress and health in aquaculture. Cambridge University Press, Cambridge, UK.

Folch, J., M. Lees, and G. H. Sloane-Stanley. 1957. A simple method for the isolation and purification of total lipids from animal tissues. Journal of Biological Chemistry 276:497-507.

Garduño, R. A., and W. W. Kay. 1994. Isolation and culture of head kidney macrophages. Pages 327-339 in P. W. Hochachka and T. P. Mommsen, editors. Analytical techniques. Biochemistry and molecular biology of fishes, volume 3. Elsevier, Amsterdam.

Gatlin, D. M. 2002. Nutrition and fish health. Pages 671-702 in J. E. Halver and R. W. Hardy, editors. Fish nutrition, 3rd edition. Academic Press, San Diego, California.

Gatta, P. P., M. Pirini, S. Testi, G. Vignola, and P. G. Monetti. 2000. The influence of different levels of dietary vitamin E on sea bass Dicentrarchus labrax flesh quality. Aquaculture Nutrition 6:47-52.

Hamre, K., R. K. Berge, and Ǿ. Lie. 1998. Oxidative stability of Atlantic salmon (Salmo salar, L.) fillet enriched in alpha-, gamma-, and delta-tocopherol through dietary supplementation. Food Chemistry 62:173-178.

Hamre, K., T. Christiansen, R. Waagbǿ, A. Maage, B. E. Torstensen, B. Lygren, Ǿ. Lie, E. Wathne, and S. Albrektsen. 2004. Antioxidant vitamins, minerals, and lipid levels in diets for Atlantic salmon (Salmo salar, L.): effects on growth performance and fillet quality. Aquaculture Nutrition 10:113-123.

Hamre, K., and Ǿ. Lie. 1997. Retained levels of dietary $\alpha-, \gamma-$, and $\delta$-tocopherol in tissues and body fluids of Atlantic salmon, Salmo salar, L. Aquaculture Nutrition 3:99-107.

Hilton, J. W. 1989. The interaction of vitamins, minerals, and diet composition in the diet of fish. Aquaculture 79:223244.

Hosomi, A., M. Arita, Y. Sato, C. Kiyose, T. Ueda, O. Igarashi, H. Arai, and K. Inoue. 1997. Affinity for $\alpha$ tocopherol transfer protein as a determinant of the biological activities of vitamin $\mathrm{E}$ analogs. FEBS (Federation of European Biochemical Societies) Letters 409:105-108.

Huang, C., and S. Huang. 2004. Effects of dietary vitamin E on growth, tissue lipid peroxidation, and liver glutathione level of juvenile hybrid tilapia, Oreochromis niloticus $\times$ O. aureus, fed oxidized oil. Aquaculture 237:381-389.

Huo, J., H. J. Nelis, P. Lavens, P. Sorgeloos, and A. P. De Leenheer. 1996. Determination of vitamin $E$ in aquatic organisms by high-performance liquid chromatography with fluorescence detection. Analytical Biochemistry 242:123-128.

Irianto, A., and B. Austin. 2002. Probiotics in aquaculture. Journal of Fish Diseases 25:633-642.

Kiron, V., J. Puangkaew, K. Ishizaka, S. Satoh, and T. Watanabe. 2004. Antioxidant status and nonspecific immune response in rainbow trout (Oncorhynchus mykiss) fed two levels of vitamin E along with three lipid sources. Aquaculture 234:361-379.

Kocabas, A. M., and D. M. Gatlin. 1999. Dietary vitamin E requirement of hybrid striped bass (Morone chrysops female $\times M$. saxatilis male). Aquaculture Nutrition 5:3-7.

Kohler, C. C. 2000. Striped bass and hybrid striped bass culture. Pages 898-907 in R. R. Stickney, editor. Encyclopedia of aquaculture. Wiley, New York.

Lin, Y-H., and S-Y. Shiau. 2005. Dietary vitamin E requirement of grouper, Epinephelus malabaricus, at two lipid levels, and their effects on immune responses. Aquaculture 248:235-244.

Magnadóttir, B. 2006. Innate immunity of fish (overview). Fish and Shellfish Immunology 20:137-151.

Mommsen, T. P., M. M. Vijayan, and T. W. Moon. 1999. Cortisol in teleosts: dynamics, mechanisms of action, and metabolic regulation. Reviews in Fish Biology and Fisheries 9:211-268.

Mulero, V., M. A. Esteban, and J. Meseguer. 1998. Effects of in vitro addition of exogenous vitamins $\mathrm{C}$ and $\mathrm{E}$ on gilthead seabream (Sparus aurata L.) phagocytes. Veterinary Immunology and Immunopathy 66:185-199.

Obach, A., C. Quentel, and F. B. Laurencin. 1993. Effects of alpha-tocopherol and dietary oxidized fish oil on the immune response of sea bass Dicentrarchus labrax. Diseases of Aquatic Organisms 15:175-185.

Ortuño, J., M. A. Esteban, and J. Meseguer. 2000. High dietary intake of $\alpha$-tocopherol acetate enhances the nonspecific immune response of gilthead seabream (Sparus aurata L.). Fish and Shellfish Immunology 10:293-307.

Peddie, S., J. Zou, and C. J. Secombes. 2002. A biologically active IL-1 $\beta$ derived peptide stimulates phagocytosis and bactericidal activity in rainbow trout, Oncorhynchus mykiss (Walbaum), head kidney leucocytes in vitro. Journal of Fish Diseases 25:351-360.

Poli, B. M., G. Parisi, F. Scappini, and G. Zampacavallo. 2005. Fish welfare and quality as affected by preslaughter and slaughter management. Aquaculture International 13:29-49.

Raa, J. 2000. The use of immune-stimulants in fish and 
shellfish feeds. Pages 47-56 in L. E. Cruz-Suárez, D. Ricque-Marie, M. Tapia-Salazar, M. A. Olvera-Novoa, and R. Civera-Cerecedo, editors. Avances en nutrición acuicola v. memorias del $\mathrm{V}$ simposium internacional de nutrición acuicola. Mérida, Yucatán.

Ruff, N., R. D. Fitzgerald, T. F. Cross, K. Hamre, and J. P. Kerry. 2003. The effect of dietary vitamin E and C level on market-size turbot (Scophthalmus maximus) fillet quality. Aquaculture Nutrition 9:91-103.

Ruff, N., R. D. Fitzgerald, T. F. Cross, and J. P. Kerry. 2002. Fillet shelf-life of Atlantic halibut Hippoglossus hippoglossus L. fed elevated levels of alpha-tocopheryl acetate. Aquaculture Research 33:1059-1071.

Ruff, N., R. D. Fitzgerald, T. F. Cross, A. Lynch, and J. P. Kerry. 2004. Distribution of alpha-tocopherol in fillets of turbot (Scophthalmus maximus) and Atlantic halibut (Hippoglossus hippoglossus) following dietary alphatocopheryl acetate supplementation. Aquaculture Nutrition 10:75-81.

Sahoo, P. K., and S. C. Mukherjee. 2002. Influence of high dietary $\boldsymbol{\alpha}$-tocopherol intakes on specific immune response, nonspecific resistance factors, and disease resistance of healthy and aflatoxin B1-induced immunocompromised Indian major carp, Labeo rohita (Hamilton). Aquaculture Nutrition 8:159-167.

Scaife, J. R., G. E. Onibi, I. Murray, T. C. Fletcher, and D. F. Houlihan. 2000. Influence of alpha-tocopherol acetate on the short- and long-term storage properties of fillets from Atlantic salmon Salmo salar fed a high lipid diet. Aquaculture Nutrition 6:65-71.

Sealey, W. M., and D. M. Gatlin III. 2002a. Dietary supplementation of vitamin C and/or vitamin E before or after experimental infection with Streptococcus iniae has limited effects on survival of hybrid striped bass. Journal of Aquatic Animal Health 14:165-174.

Sealey, W. M., and D. M. Gatlin III. 2002b. Dietary vitamin C and vitamin $\mathrm{E}$ interact to influence growth and tissue composition of juvenile hybrid striped bass (Morone chrysops $+\times M$. saxatilis $\widehat{0})$ but have limited effects on immune responses. Journal of Nutrition 132:748-755.

Sealey, W. M., and D. M. Gatlin III. 2002c. In vitro manipulations of vitamin $\mathrm{C}$ and vitamin $\mathrm{E}$ concentrations alter intracellular $\mathrm{O}_{2}$-production of hybrid striped bass
(Morone chrysops $\times$ M. saxatilis). Fish and Shellfish Immunology 12:131-140.

Secombes, C. J. 1990. Isolation of salmonid macrophages and analysis of their killing activity. Pages 137-154 in J. S. Stolen, T. C. Fletcher, D. P. Anderson, B. S. Roberson, and W. B. van Muiswinkel, editors. Techniques of fish immunology, volume 1. SOS Publications, Fair Haven, New Jersey.

Stéphan, G., J. Guillaume, and F. Lamour. 1995. Lipid peroxidation in turbot (Scophthalmus maximus) tissue: effect of dietary vitamin $\mathrm{E}$ and dietary $\mathrm{n}-6$ or $\mathrm{n}-3$ polyunsaturated fatty acids. Aquaculture 130:251-268.

Stone, W. L., and A. Papas. 2003. Tocopherols, tocotrienols, and vitamin E. Pages 53-72 in F. D. Gunstone, editor. Lipids for functional foods and nutraceuticals. Oily Press, Bridgwater, UK.

Tocher, D. R., G. Mourente, A. Van der Eecken, J. O. Evjemo, E. Diaz, J. G. Bell, I. Geurden, P. Lavens, and Y. Olsen. 2002. Effects of dietary vitamin E on antioxidant defence mechanisms of juvenile turbot (Scophthalmus maximus L.), halibut (Hippoglossus hippoglossus L.) and sea bream (Sparus aurata L.). Aquaculture Nutrition 8:195-207.

Tocher, D. R., G. Mourente, A. Van der Eecken, J. O. Evjemo, E. Diaz, M. Wille, J. G. Bell, and Y. Olsen. 2003. Comparative study of antioxidant defence mechanisms in marine fish fed variable levels of oxidized oil and vitamin E. Aquaculture International 11:195-216.

Tort, L., J. C. Balasch, and S. MacKenzie. 2004. Fish health challenge after stress: indicators of immunocompetence. Contributions to Sciences 2:443-454.

Trushenski, J. T., and C. C. Kohler. 2006. Evaluation of natural source vitamin $\mathrm{E}, R R R$-alpha tocopheryl acetate, as a micronutrient in sunshine bass feed. North American Journal of Aquaculture 68:186-191.

Wahli, T., V. Verlhac, J. Gabaudan, W. Schüep, and W. Meier. 1998. Influence of combined vitamins $\mathrm{C}$ and $\mathrm{E}$ on non-specific immunity and disease resistance of rainbow trout, Oncorhynchus mykiss (Walbaum). Journal of Fish Diseases 21:127-137.

Zingg, J., and A. Azzi. 2004. Non-antioxidant activities of vitamin E. Current Medicinal Chemistry 11:1113-1133. 